\title{
Emerging technology of in situ cell free expression protein microarrays
}

\author{
Amita Nand", Anju Gautam², Javier Batista Pérez ${ }^{1}$, Alejandro Merino ${ }^{1}$, Jinsong Zhu ${ }^{1 凶}$ \\ ${ }^{1}$ National Center for Nanoscience and Technology, Chinese Academy of Sciences, Beijing 100190, China \\ ${ }^{2}$ Institute of Microbiology, Chinese Academy of Sciences, Beijing 100101, China \\ $\bowtie$ Correspondence: jizhu88@gmail.com
}

Erratum to: Protein Cell 2012, 3(2): 84-88

DOI 10.1007/s13238-012-2012-y
Due to a typesetting error, $\left(\sim 3-7 \times 10^{13} \mathrm{~mol} / \mathrm{L}\right)$ in the fifth line of the "TUS-TER microarray" subsection on the right column of page 85 should be $\left(\sim 3-7 \times 10^{-13} \mathrm{~mol} / \mathrm{L}\right)$.

The online version of the original article can be found at http://dx.doi.org/10.1007/ s13238-012-2012-y 